\title{
Faktor-faktor yang Mempengaruhi Partisipasi Ibu Membawa Balita ke Posyandu RW 038 Bojong Rawalumbu
}

\author{
Mastiur Dewi Manurung ${ }^{1}$, Hari Ghanesia Istiani ${ }^{2}$ \\ ${ }^{1,2}$ Program Studi Sarjana Keperawatan \\ Sekolah Tinggi Ilmu Kesehatan Indonesia Maju, Jakarta - Indonesia \\ Email:1'mastiurdewi@gmail.com,r2ghanesia30@gmail.com
}

\begin{abstract}
Latar Belakang: Balita merupakan golongan yang rentan terhadap masalah kesehatan. Gangguan kesehatan yang terjadi pada balita mempengaruhi pertumbuhan dan perkembangan baik pada masa balita maupun masa berikutnya.

Tujuan: Tujuan penelitian ini adalah untuk mengetahui faktorfaktor yang mempengaruhi partisipasi ibu membawa balita ke Posyandu RW 038 Bojong Rawa Lumbu Bekasi.

Metode: Penelitian ini dilakukan pada 35 orang responden, menggunakan desain penelitian chi-square. Sampling menggunakan total sampling.

Hasil: Hasil penelitian ini menunjukkan bahwa terdapat hubungan antara pendidikan ibu terhadap partisipasi ibu membawa balita ke posyandu dengan hasil analisa $p$-value 0,026 ( $p$-value $<0,05)$, terdapat hubungan antara pekerjaan ibu terhadap partisipasi ibu membawa balita ke posyandu dengan hasil analisa $p$-value 0,001 (p-value $<0,05$ ), terdapat hubungan jarak ke posyandu terhadap partisipasi ibu membawa balita ke posyandu dengan hasil analisa p-value 0,000 ( $\mathrm{p}$-value $<0,05$ ), terdapat hubungan antara pengetahuan ibu terhadap partisipasi ibu membawa balita ke posyandu dengan hasil analisa $p$-value 0,015 ( $\mathrm{p}$-value $<0,05$ ). Diharapkan pemerintah dalam hal ini puskesmas menyediakan sarana dan prasarana untuk mendukung penyelenggaraan kegiatan posyandu.
\end{abstract}

Kata Kunci: Partisipasi Ibu, Balita, Posyandu.

Editor: WN

Hak Cipta:

C2021 Artikel ini memiliki akses terbuka dan dapat didistribusikan berdasarkan ketentuan Lisensi Atribusi Creative Commons, yang memungkinkan penggunaan, distribusi, dan reproduksi yang tidak dibatasi dalam media apa pun, asalkan nama penulis dan sumber asli disertakan. Karya ini dilisensikan di bawah Lisensi Creative Commons Attribution-Share Alike 4.0 Internasional.

\section{Pendahuluan}

Rencana Pembangunan Jangka Menengah (RPJM) 2010 - 2014 Bidang Kesehatan ditetapkan dengan harapan mampu memberikan kesejahteraan kepada masyarakat, khususnya dalam Bidang Kesehatan. Tujuan dari rencana tersebut dapat dinilai dari indikator Sumber Daya Manusia. seperti meningkatnya status gizi masyarakat, kesetaraan gender dan tumbuh kembang yang optimal. ${ }^{1}$ Salah satu indikator derajat kesehatan masyarakat di Indonesia adalah angka kematian ibu, angka kematian 
bayi, dan angka kematian balita yang masih tinggi. Angka Kematian Ibu (AKI), Angka Kematian Bayi (AKB) dan Angka Kematian Balita (AKABA) dimana jika AKB dan AKI naik, maka derajat kesehatan masyarakat masih rendah dan sebaliknya. ${ }^{2}$

Berdasarkan data dari Dinas Kesehatan Jawa Barat pada tahun 2012, prevalensi balita dengan gizi kurang sebesar $8,60 \%$ dan prevalensi balita dengan gizi buruk sebesar $0,58 \%$ balita di Jawa Barat serta tingkat partisipasi masyarakat dalam penimbangan di Posyandu $(\mathrm{D} / \mathrm{S})$ rata rata sebesar $84 \%$ (meningkat dibanding tahun 2011 sekitar 70-79\%) di semua kab/kota. ${ }^{3}$ Berdasarkan data dari Dinas Kesehatan Kota Bekasi pada tahun 2013, pemantauan status gizi Balita di Kota Bekasi melaporkan Balita Gizi Buruk ada 50 Balita. Balita Gizi Buruk sebesar 0,22\% (BB/U) dan jumlah Gizi Buruk dilaporkan sebesar 50 balita gizi buruk (BB/TB). Tingkat partisipasi masyarakat dalam penimbangan di Posyandu (D/S) Pada tahun 2011 sebesar 75,3\%, tahun 2012 sebesr 76,4\% dan tahun 2013 sebesar77,75\%, walaupun mengalami peningkatan, tetapi masih dibawah target $80 \%{ }^{2}$

Masalah gangguan kesehatan pada Balita sangat sering terjadi. Hal tersebut akan mempengaruhi tumbuh kembang Balita hingga fase berikutnya. Sehingga masalah tersebut membutuhkan perhatian khusus, dengan adanya Posyandu (Pos Pelayanan Terpadu) pertumbuhan dan perkembangan Balita akan terpantau. Cakupan pelayanan gizi balita, cakupan pelayanan kesehatan seperti imunisasi serta prevalensi kurang gizi dapat dilihat dari cakupan penimbangan balita di posyandu. cakupan penimbangan balita ditunjukkan dengan presentase jumlah balita yang datang dibagi jumlah balita keseluruhan. Semakin tinggi nilai cakupan penimbangan balita maka semakin tinggi cakupan Vitamin A, semakin tinggi cakupan imunisasi dan semakin rendah prevalensi kurang gizi. $^{4}$

Posyandu merupakan salah satu bentuk Upaya Kesehatan Bersumber Daya Masyarakat (UKBM) dan juga merupakan salah satu kegiatan LKMD (Lembaga Ketahanan Masyarakat Desa). Kegiatan ini dalam rangka penyelenggaraan pembangunan kesehatan yang dikelola oleh masyarakat yang kemudian dapat memberdayakan dan memberi kemudahan kepada masyarakat untuk memperoleh pelayanan kesehatan dasar sehingga diharapkan dapat mengurangi angka kematian pada ibu dan bayi. Salah satu tujuan Posyandu adalah meningkatkan kesehatan ibu dan balita, tercapainya tujuan tersebut dapat dilihat dari tingkat kehadiran Ibu dan Balita di Posyandu. Hal tersebut juga merupakan salah satu indikator keberhasilan pemanfaatan pelayanan kesehatan khususnya Posyandu.

Posyandu diselenggarakan oleh kader yang telah terlatih secara terpadu dengan bantuan dari petugas Puskesmas pada tempat dan waktu tertentu. Kader tersebut dilatih untuk menyelenggarakan 5 program prioritas. Sasaran pelayanan kesehatan di Posyandu mulai dari bayi (usia kurang dari 1 tahun), anak balita (usia 1-5 tahun), ibu hamil, ibu menyusui dan wanita PUS (pasangan usia subur). Posyandu berperan dalam menanggulangi ancaman gizi buruk dan gizi kurang sehingga manfaat Posyandu sebagai salah satu Pusat Pemulihan gizi (PPG). Sebelum ke puskesmas atau rumah sakit, Posyandu juga merupakan pelayanan kesehatan paling pertama yang dapat dimanfaatkan oleh masyarakat seperti Balita. Kesadaran masyarakat akan pentingnya kesehatan dapat ditingkatkan dengan adanya Posyandu, hal ini disebabkan karena posyandu dapat dengan mudah dijangkau oleh masyarakat sebagai penyedia layanan kesehatan yang paling dekat dan vital bagi masyarakat. Posyandu sangat memegang peranan penting dalam masyarakat, akan tetapi masuh banyak sejumlah masyarakat yang tidak memanfaatkn fasilitas dan pelayanan kesehatan secara maksimal. Hal tersebut dapat dilihat dari masih rendahnya proporsi perbandingan antara jumlah balita yang dibawa ke 
posyandu dengan jumlah balita secara keseluruhan dalam satu wilayah kerja posyandu, yang nilanya masih dibawah standar, standar pelayanan minimal untuk D/S adalah $80 \%{ }^{5}$

Gambaran perilaku masyarakat yang termasuk didalamnya ibu yang mempunyai balita dalam memanfaatkan sarana pelayanan kesehatan yang ada didaerahnya dapat terlihat dari tingkat keberhasilan program Posyandu yaitu cakupan penimbangan balita di Posyandu. Menurut Lawrence Green Dalam buku tentang pendidikan dan perilaku kesehatan, tentunya ada beberapa faktor yang mempengaruhi perilaku individu yang termasuk didalamnya ibu yang mempunyai balita dalam hal perilaku yang berhubungan dengan kesehatan diantaranya adalah faktor predisposisi (pengetahuan, pendidikan, status pekerjaan, umur, dan lain-lain), faktor pendukung (lingkungan fisik, jarak ke posyandu, tersedia atau tidak tersedianya fasilitas atau sarana kesehatan), dan faktor pendorong (yang terwujud dalam sikap dan perilaku petugas kesehatan). Masalah-masalah lain yang menentukan kunjungan masyarakat di posyandu yaitu kurangnya sarana prasarana dan biaya operasional, tingkat pengetahuan kader, kemampuan petugas dalam memantau tumbuh kembang dan pemberian konseling, pelaksanaan pelatihan kader, tingkat pemahaman orang tua, keluarga serta anggota masyarakat dalam memanfaatkan posyandu. ${ }^{6}$

Kurang gizi pada balita dan ibu hamil dapat dicegah dengan rutin memeriksakan diri ke posyandu, puskesmas atau pusat pelayanan kesehatan lainnya. Namun banyak dari mereka tidak memperhatikan hal tersebut karena orang tuanya tidak mengerti tentang manfaat posyandu. Pelayanan kesehatan pada posyandu juga cenderung tidak lengkap, anak hanya ditibang berat badannya namun orang tua tidak mendapat pendidikan gizi untuk anaknya. Akan tetapi, sejak era desentralisasi, banyak pos pelayanan terpadu tidak berjalan semestinya akibat rendahnya perhatian pemerintah daerah.

Dampak yang mungkin akan dialami balita apabila ibu balita tidak aktif dalam kegiatan posyandu antara lain yaitu sebagai berikut: tidak mendapatkan penyuluhan kesehatan tentang pertumbuhan balita yang normal, tidak mendapatkan vitamin A untuk kesehatan mata balita dan ibu balita tidak mendapatkan pemberian dan penyuluhan tentang makanan tambahan (PMT). Maka dari itu dengan aktif dalam kegiatan posyandu ibu balita diharapkan dapat memantau pertumbuhan dan perkembangan balitanya dengan baik. $^{7}$

Kunci utama keberhasilan suatu posyandu terletak pada tingginya partisipasi ibu dan balita dalam memperbaiki status gizi anak. Faktor lain yg menentukan keberhasilan suatu posyandu yaitu partisipasi masyarakat termasuk kader posyandu, pengguna posyandu dan tokoh masyarakat, peran petugas Puskesmas dan petugas KB serta peran sector lain. Berdasarkan hasil studi pendahuluan didapatkan hasil wawancara dengan bidan koordinator posyandu balita di Puskesmas Rawa Lumbu dan kader posyandu RW 038 Bojong Rawa Lumbu di wilayah kerja Puskesmas Rawa Lumbu yang dilaksanakan pada tanggal 11 Februari 2018, dari data sekunder didapatkan jumlah balita 169 pada tahun 2017.

Pada hasil studi pendahuluan dan wawancara ke dua pada tanggal 16 Februari 2018 yaitu di wilayah kerja puskesmas Rawa Lumbu terdapat 50 posyandu yang aktif serta strata posyandu purnama ada 23 dan mandiri ada 23 posyandu dan strata posyandu madya ada 4 posyandu. Kemudian posyandu RW 038 Bojong Rawa Lumbu merupakan posyandu yang berstrata mandiri, diadakan setiap hari selasa minggu pertama setiap bulannya dan sudah menggunakan sistem 5 meja dalam pelayanannya dan jumlah balita sebanyak 35 balita. Faktor-faktor yang mempengaruhi ibu balita yang tidak membawa anaknya ke posyandu untuk di timbang di posyandu RW 038 Bojong Rawa Lumbu dikarenakan ibu-ibu balita sibuk bekerja, sudah memiliki dokter pribadi, ketika jadwal posyandu 


\section{J INDONESIA JOURNAL \\ of Miduifery sciences}

anaknya sedang tidur, tidak ada yang mengantar ke posyandu. Dan ketika bulannya vitamin A di bulan Februari dan Agustus banyak ibu-ibu balita yang datang ke posyandu. ${ }^{8}$

Berdasarkan hasil wawancara pada 10 orang ibu, peneliti menemukan bahwa 8 ibu sering mengunjungi posyandu, dikarenakan tempat posyandu yang dekat dengan rumah, serta posyandu juga sering memberikan informasi mengenai ibu dan anak. Sedangkan 2 ibu lainnya jarang membawa ke posyandu, karena kesibukan bekerja walaupun pada hari libur. Hasil wawancara peneliti dengan para kader posyandu, didapatkan bahwa ibu yang sering membawa balita ke posyandu adalah ibu yang tidak bekerja (ibu rumah tangga). Selain itu, para kader juga aktif memberikan informasi kepada para ibu bila waktu posyandu sudah dekat. Petugas Puskesmas juga aktif mengunjungi posyandu dan memberikan pendidikan kesehatan, sehingga para ibu antusias untuk mengikuti posyandu tiap minggunya. Dari wawancara tersebut dapat disimpul-kan bahwa jarak posyandu berpegaruh dalam partisipasi ibu, peran kader dalam meberikan infomasi, serta hubungan yang baik antara kader dan ibu juga mempengaruhi partisipasi ibu dalam mengunjungi posyandu.

Metode

Desain penelitian yang digunakan adalah jenis penelitian deskriptif korelasi dengan menggunakan pendekatan cross sectional yaitu pengumpulan data penelitian yang dilaksanakan sekaligus pada suatu saat Penelitian ini bertujuan untuk mengidentifikasi faktor-faktor yang mempengaruhi partisipasi ibu membawa balita ke Posyandu RW 038 Bojong Rawa Lumbu Bekasi. ${ }^{9}$

Populasi dalam penelitian ini para ibu yang memiliki balita yang membawa anaknya ke Posyandu RW 038 Bojong Rawa Lumbu dengan jumlah populasi sebanyak 35 orang. Jumlah ini diambil dari total kunjungan terakhir pada bulan Desember 2017. Sampel penelitian ini adalah para ibu yang memiliki balita yang membawa anaknya ke Posyandu RW 038 Bojong Rawa Lumbu, dengan jumlah sampel 35 orang. Teknik pengambilan sampel dalam penelitian ini menggunakan teknik Total Sampling. ${ }^{10}$

Penelitian ini dimulai pada bulan Februari 2018 sampai dengan bulan Mei 2018 pada hari selasa minggu pertama. Instrumen yang digunakan untuk mengumpulkan data dalam penelitian ini berupa berupa kuesioner tentang informasi umum responden termasuk pertanyaan tentang pengetahuan ibu sebanyak 20 buah pertanyaan, yang diambil dari beberapa kuesioner, dan telah di modifikasi sedemikian rupa sehingga pertanyaan- pertanyaan dalam penelitian sesuai untuk digunakan pada responden di Posyandu RW 038 Bojong Rawa Lumbu.

Analisa statistik melalui dua tahapan yaitu menggunakan analisa univariat dan bivariat. Analisis univariat dilakukan untuk menjelaskan data demografi, variabel pengetahuan ibu. Sementara analisis bivariat digunakan untuk mengetahui hubungan Faktor-Faktor yang Mempengaruhi Partisipasi Ibu Balita ke Posyandu. Pada penelitian ini digunakan uji chi-square, yang bertujuan untuk mengetahui hubungan atau pengaruh dua buah variabel.

Hasil

Tabel 1. Distribusi Frekuensi Berdasarkan Karakteristik Respnden

\begin{tabular}{cccc}
\hline \multirow{2}{*}{ Karakteristik responden } & Jumlah & Persentase \\
\cline { 2 - 4 } & $\begin{array}{c}\text { Pendidikan Ibu } \\
\text { a. Rendah }\end{array}$ & n & \% \\
\hline 1. & 12 & 34,3 \\
\hline
\end{tabular}




\section{J INDONESIA JOURNAL of Miduifery scIences}

\begin{tabular}{|c|c|c|c|}
\hline & b. Tinggi & 23 & 65,7 \\
\hline & Total & 35 & 100 \\
\hline \multirow[t]{4}{*}{2.} & Pekerjaan Ibu & & \\
\hline & a. Tidak Bekerja & 14 & 40,0 \\
\hline & b. Bekerja & 21 & 60,0 \\
\hline & Total & 35 & 100 \\
\hline \multirow[t]{4}{*}{3.} & Jarak ke Posyandu & & \\
\hline & a. Dekat & 26 & 74,3 \\
\hline & b. Jauh & 9 & 25,7 \\
\hline & Total & 35 & 100 \\
\hline \multirow[t]{4}{*}{4.} & Pengetahuan Ibu & & \\
\hline & a. Tinggi & 27 & 77,1 \\
\hline & b. Rendah & 8 & 22,9 \\
\hline & Total & 35 & 100 \\
\hline \multirow[t]{4}{*}{5.} & Partisipasi Ibu & & \\
\hline & a. Tidak Aktif & 9 & 25,7 \\
\hline & b. Aktif & 26 & 74,3 \\
\hline & Total & 35 & 100 \\
\hline
\end{tabular}

Berdasarkan tabel 1 diatas menunjukan hasil bahwa responden penelitian pendidikan ibu mayoritas responden pendidikan tinggi sebanyak 23 (65,7\%) reponden, pekerjaan ibu mayoritas responden bekerja sebanyak $21(60 \%)$ reponden, jarak ke posyandu mayoritas responden jarak ke posyandu dekat sebanyak $26(74,3 \%)$ reponden, pengetahuan ibu mayoritas responden pengetahuan baik sebanyak $27(77,1 \%)$ reponden, dan partisipasi ibu mayoritas responden partisipasi aktif sebanyak $26(74,3 \%)$ reponden.

Tabel 2. Hubungan Pendidikan Ibu terhadap Partisipasi Ibu Membawa Balita Ke Posyandu $(n=35)$

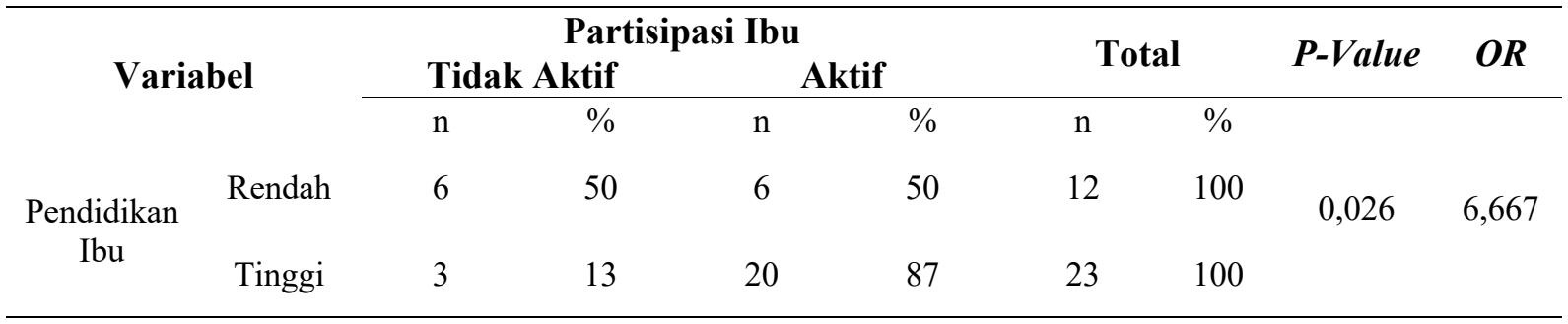

Berdasarkan tabel 2 terlihat bahwa responden pendidikan tinggi dengan partisipasi aktif sebanyak 20 orang $(87 \%)$. Hasil uji statistik didapatkan nilai $p$-value adalah $0,026(\mathrm{p}<0,05)$. Sehingga dapat disimpulkan adanya hubungan pendidikan ibu dengan partisipasi membawa balita ke posyandu.

Tabel 3. Hubungan Pekerjaan Ibu terhadap Partisipasi Ibu Membawa Balita Ke Posyandu ( $\mathrm{n}=35)$

\begin{tabular}{|c|c|c|c|c|c|c|c|c|c|}
\hline \multirow{3}{*}{\multicolumn{2}{|c|}{ Variabel }} & \multicolumn{4}{|c|}{ Partisipasi Ibu } & \multirow{2}{*}{\multicolumn{2}{|c|}{ Total }} & \multirow{3}{*}{ P-Value } & \multirow{3}{*}{ OR } \\
\hline & & \multicolumn{2}{|c|}{ Tidak Aktif } & \multicolumn{2}{|c|}{ Aktif } & & & & \\
\hline & & $\mathrm{n}$ & $\%$ & $\mathrm{n}$ & $\%$ & $\mathrm{n}$ & $\%$ & & \\
\hline \multirow{2}{*}{$\begin{array}{l}\text { Pekerjaan } \\
\text { Ibu }\end{array}$} & $\begin{array}{c}\text { Tidak } \\
\text { Bekerja }\end{array}$ & 8 & 57,1 & 6 & 42,9 & 14 & 100 & \multirow[t]{2}{*}{0,001} & \multirow[t]{2}{*}{26,667} \\
\hline & Bekerja & 1 & 4,8 & 20 & 95,2 & 21 & 100 & & \\
\hline
\end{tabular}




\section{J INDONESIA JOURNAL of Miduifery sciences}

Berdasarkan tabel 3 terlihat bahwa responden yang bekerja dengan partisipasi aktif sebanyak 20 orang $(95,2 \%)$. Hasil uji statistik didapatkan nilai $p$-value adalah $0,001(\mathrm{p}<0,05)$. Sehingga dapat disimpulkan adanya hubungan antara pekerjaan ibu terhadap partisipasi ibu membawa balita ke posyandu.

Tabel 4. Hubungan Jarak ke Posyandu dengan Partisipasi Ibu Membawa Balita Ke Posyandu ( $\mathrm{n}=35)$

\begin{tabular}{|c|c|c|c|c|c|c|c|c|c|}
\hline \multirow{3}{*}{\multicolumn{2}{|c|}{ Variabel }} & \multicolumn{4}{|c|}{ Partisipasi Ibu } & \multirow{2}{*}{\multicolumn{2}{|c|}{ Total }} & \multirow{3}{*}{$\begin{array}{c}P- \\
\text { Value }\end{array}$} & \multirow{2}{*}{$O R$} \\
\hline & & \multicolumn{2}{|c|}{ Tidak Aktif } & \multicolumn{2}{|c|}{ Aktif } & & & & \\
\hline & & $\mathrm{n}$ & $\%$ & $\mathrm{n}$ & $\%$ & $\mathrm{n}$ & $\%$ & & \multirow{3}{*}{26,667} \\
\hline \multirow{2}{*}{$\begin{array}{l}\text { Pekerjaan } \\
\text { Ibu }\end{array}$} & $\begin{array}{c}\text { Tidak } \\
\text { Bekerja }\end{array}$ & & 57,1 & 6 & 42,9 & 14 & 100 & \multirow[t]{2}{*}{0,001} & \\
\hline & Bekerja & 1 & 4,8 & 20 & 95,2 & 21 & 100 & & \\
\hline
\end{tabular}

Berdasarkan tabel 4 terlihat bahwa responden yang jarak ke posyandu dekat dengan partisipasi aktif sebanyak 24 orang (92,3\%). Hasil uji statistik didapatkan nilai $p$-value adalah $0,000(\mathrm{p}<0,05)$. Sehingga dapat disimpulkan adanya hubungan antara jarak ke posyandu terhadap partisipasi ibu membawa balita ke posyandu.

Tabel 5. Hubungan Pengetahuan Ibu terhadap Partisipasi Ibu Membawa Balita ke Posyandu $(\mathrm{n}=35)$

\begin{tabular}{|c|c|c|c|c|c|c|c|c|c|}
\hline \multirow{3}{*}{\multicolumn{2}{|c|}{ Variabel }} & \multicolumn{4}{|c|}{ Partisipasi Ibu } & \multirow{2}{*}{\multicolumn{2}{|c|}{ Total }} & \multirow{3}{*}{$\begin{array}{c}P- \\
\text { Value }\end{array}$} & \multirow{3}{*}{$O R$} \\
\hline & & \multicolumn{2}{|c|}{ Tidak Aktif } & \multicolumn{2}{|c|}{ Aktif } & & & & \\
\hline & & $\mathrm{n}$ & $\%$ & $\mathrm{n}$ & $\%$ & $\mathrm{n}$ & $\%$ & & \\
\hline \multirow{2}{*}{$\begin{array}{c}\text { Pekerjaan } \\
\text { Ibu }\end{array}$} & $\begin{array}{c}\text { Tidak } \\
\text { Bekerja }\end{array}$ & 8 & 57,1 & 6 & 42,9 & 14 & 100 & \multirow[t]{2}{*}{0,001} & \multirow[t]{2}{*}{26,667} \\
\hline & Bekerja & 1 & 4,8 & 20 & 95,2 & 21 & 100 & & \\
\hline
\end{tabular}

Berdasarkan tabel 5 terlihat bahwa responden pengetahuan tinggi dengan partisipasi aktif sebanyak 23 orang $(85,2 \%)$. Hasil uji statistik didapatkan nilai $p$-value adalah 0,015 ( $<<0,05)$. Sehingga dapat disimpulkan adanya hubungan antara pengetahuan ibu terhadap partisipasi ibu membawa balita ke posyandu.

\section{Pembahasan}

Berdasarkan hasil penelitian menunjukkan sebagian besar responden dengan pendidikan tinggi sebanyak $23(65,7 \%)$ reponden. Menurut penelitian yang dilakukan Suryaningsih (2012) untuk katregori pendidikan didapatkan bahwa sebanyak $(56,6 \%)$ responden berpendidikan tamat SMA. Tingkat pendidikan dapat menentukan kemudahan seseorang untuk dapat menerima dan mencari informasi serta menerapkannya dalam perilaku dan pola hidup sehari-hari. Semakin tinggi tingkat pendidikan seseorang maka semakin mudah baginya untuk menerima dan mecari informasi. tingkat pendidikan orang tua mempunyai pengaruh besar dalam kehidupan keluarga, khususnya tingkat pendidikan ibu yang dinilai mempunyai pengaruh yang lebih besar pada kehidupan di dalam keluarga khususnya bagi tumbuh kembang dan kesehatan anaknya, hal ini disebabkan Ibu mempunyai peranan 
dan tanggung jawab lebih besar dalam mengasuh, membesarkan anak dan perawatan anak serta keluarga. ${ }^{11}$

Hasil penelitian menunjukkan sebagian besar responden dengan pekerjaan ibu mayoritas responden bekerja sebanyak $21(60 \%)$ reponden. Menurut hasil penelitian menunjukkan bahwa sebagian besar pekerjaan responden adalah petani yaitu sebanyak 84 orang $(60 \%)$. Hardinsyah dan Suhardjo (1987) menyatakan bahwa tingkat pendidikan seseorang akan mempengaruhi jenis pekerjaan seseorang. Semakin tinggi tingkat pendidikan seseorang maka peluang untuk mendapatkan pekerjaan juga semakin tinggi sedangkan tingkat pengetahuan seseorang dipengaruhi oleh jenis pekerjaan seseorang. Seseorang yang bekerja pada lingkungan yang memungkinkan akses informasi yang mudah memiliki tingkat pengetahuan yang lebih baik dibandingkan dengan jenis pekerjaan yang tidak memungkinkan untuk mengakses informasi.

Berdasarkan hasil penelitian menunjukkan sebagian besar responden dengan jarak ke posyandu mayoritas responden jarak ke posyandu dekat sebanyak $26(74,3 \%)$ reponden. Menurut penelitian jarak rumah dekat dengan partisipasi aktif menimbang balitanya ke Posyandu 56,9.\%. Tempat penyelenggaraan kegiatan posyandu sebaiknya berada pada lokasi yang mudah dijangkau oleh masyarakat. Untuk memudahkan jangkauan masyarakat pada kegiatan Posyandu maka tempat pelaksanaan kegiatan tersebut bisa diselenggarakan di salah satu rumah warga, balai desa/kelurahan, halaman rumah, balai RT/RW atau dusun, kios pasar atau tempat lainnya yang dibangun seacra swadaya oleh masyarakat yang memungkinkan untuk kegiatan posyandu. ${ }^{1}$ Apabila tempat atau lokasi penyelenggaraan kegiatan Posyandu berlokasi jauh maka setidaknya tempat tersebut harus mempunyai fasilitas kesehatan yang lebih lengkap serta pelayanan kesehatan yang maksimal. ${ }^{12}$

Berdasarkan hasil penelitian menunjukkan sebagian besar responden dengan pengetahuan ibu mayoritas responden pengetahuan baik sebanyak 27 (77,1\%) reponden. Hal ini sejalan dengan penelitian menunjukan hasil responden yang memiliki pengetahuan baik sebesar 58,3\%. Menurut Nursalam (2008) menyebutkan bahwa tingkat pendidikan berhubungan dengan tingkat kemudahan seseorang dalam menerima informasi, semakin tinggi tingkat pendidikan seseorang maka kemampuan untuk menerima informasi semakin baik sehingga seseorang dengan tingkat pendidikan yang tinggi memiliki lebih banyak pengetahuan. Hal ini menjelaskan bahwa pengetahuan sangat berkaitan dengan tingkat pendidikan dengan harapan bahwa seseorang dengan tingkat pendidikan yang lebih tinggi memiliki pengetahuan yg lebih luas. Namun perlu diingat bahwa pengetahuan tidak hanya bisa didapatkan dari pendidikan formal tetapi juga bisa didapatkan dari pendidikan informal. ${ }^{13}$

Hasil penelitian menunjukkan sebagian besar responden dengan partisipasi ibu mayoritas responden partisipasi aktif sebanyak $26(74,3 \%)$ reponden. Menurut penelitian yang dilakukan, responden yang mempunyai bayi dan balita yang memiliki perilaku partisipasi baik berkunjung ke posyandu $\geq 4$ kali pada tahun 2012 yaitu sebesar $83 \%$. Faktor pendukung yang sangat penting dalam pemantauan pertumbuhan dan perkembangan anak sal satunya adalah partisipasi ibu balita dalam kegiatan posyandu. Tingkat partisipasi ibu dapat dilihat dari perbandingan jumlah anak yang ditimbang dengan jumlah anak keseluruhan pada wilayah tersebut $(\mathrm{D} / \mathrm{S}) .{ }^{14}$ Tingkat partisipasi masyarakat atau dalam hal ini ibunya minimal harus mencapai $80 \%$, apabila tingkat partisipasi masyarakat dibawah angka tersebut maka bisa dikatakan bahwa kegiatan dalam memantau tumbuh kembang anak pada wilayah tersebut masih sangat rendah sehingga hal ini harus menjadi perhatian khusus bagi kader posyandu. Apabila tingkat partisipasi masyarakat masih rendah maka tumbuh kembang anak pada wilayah tersebut akan sulit untuk dipantau sehingga masalah-masalah kesehatan 
balita bisa saja akan meningkat. ${ }^{15}$

\section{Hubungan Pendidikan Ibu terhadap Partisipasi Ibu Membawa Balita ke Posyandu}

Berdasarkan hasil penelitian didapat bahwa responden pendidikan tinggi dengan partisipasi aktif sebanyak 20 orang (87\%). Hasil uji statistik didapatkan nilai $p$-value adalah $0,026(\mathrm{p}<0,05)$. Sehingga dapat disimpulkan adanya hubungan antara pendidikan ibu terhadap partisipasi ibu membawa balita ke posyandu. Hal ini sesuai dengan penelitian yang menyatakan bahwa ada hubungan yang bermakna antara pendidikan ibu dengan perilaku kunjungan ibu balita ke posyandu. Penelitian melaporkan terdapat hubungan antara pendidikan dengan pemanfaatan pelayanan Posyandu oleh ibu dengan Balita. ${ }^{16}$

Hasil penelitian ini sejalan dengan penelitian yang dilakukan memperlihatkan proposi responden berpendidikan tinggi dan berprilaku kunjungan baik sebesar $82,5 \%$ dengan nilai $p$-value 0,006 . Pendidikan orang tua merupakan kunci keberhasilan tumbuh kembang seorang anak di dalam keluarga terutama pendidikan ibu karena dianggap memiliki pengaruh yag lebih besar. Hal ini disebabkan karena ibu memiliki peran dan tanggung jawab yang lebih besar pada pola asuh, perawatan serta kesehatan anak dan keluarga. Tingkat pendidikan ibu yang tinggi diharapkan akan memudahkan ibu tersebut untuk menerima dan mencari informasi serta menerapkan informasi yang dia dapatkan pada pola hidup sehat sehari-hari. ${ }^{17}$

\section{Hubungan Pekerjaan Ibu terhadap Partisipasi Ibu Membawa Balita ke Posyandu}

Berdasarkan hasil penelitian didapat bahwa responden yang bekerja dengan partisipasi aktif sebanyak 20 orang $(95,2 \%)$. Hasil uji statistik didapatkan nilai $p$-value adalah $0,001(\mathrm{p}<0,05)$. Sehingga dapat disimpulkan adanya hubungan antara pekerjaan ibu terhadap partisipasi ibu membawa balita ke posyandu.

Hasil penelitian ini sejalan dengan penelitian yang dilakukan oleh Suryaningsih (2012) proporsi responden yang bekerja mempunyai perilaku kunjungan baik sebesar $71,4 \%$ dengan nilai $p$ value 0,038 . Sedangkan hasil penelitian ini berbeda dengan penelitian yang menemukan bahwa ibu yang tidak bekerja atau ibu rumah tangga yang aktifitas sehari-harinya hanya di rumah saja akan memiliki peluang yang lebih besarfaatkan fasilitas kesehatan seperti posyandu dibandingkan dengan ibu pekerja. ${ }^{18}$

\section{Hubungan Jarak Ke Posyandu terhadap Partisipasi Ibu Membawa Balita ke Posyandu}

Berdasarkan hasil penelitian didapat bahwa bahwa responden yang jarak ke posyandu dekat dengan partisipasi aktif sebanyak 24 orang $(92,3 \%)$. Hasil uji statistik didapatkan nilai $p$-value adalah $0,000(\mathrm{p}<0,05)$. Sehingga dapat disimpulkan adanya hubungan antara jarak ke posyandu terhadap partisipasi ibu membawa balita ke posyandu.

Menurut hasil penelitian Wilianarti (2017) faktor keterjangkauan tempat pelayanan kesehatan menunjukkan $(\mathrm{p}=0,003<\alpha=0,05)$. Sehingga dapat dinyatakan ada pengaruh keterjangkauan dalam meberperan aktif diposyandu. Hasil penelitian ini sejalan dengan penelitian yang dilakukan oleh Suryaningsih (2012) proporsi kelompok responden yang jarak posyandu dari rumah $<1 \mathrm{~km}$ dan mempunyai perilaku kunjungan baik sebesar $84,8 \%$ dengan nilai $p$-value $0,003 .{ }^{19}$

Penelitain sebelumnya menunjukkan bahwa keaktifan masyarakat dalam posyandu untuk memeriksakan balitanya secara rutin sangat dipengaruhi oleh kondisi geografis seperti jarak dan 
kondisi jalanan menuju ke tempat pelayanan posyandu. Semakin jauh jaraknya maka jumlah masyarakat yg berpartisipasi akan menjadi lebih sedikit. Maka dari itu lokasi penyelenggaran posyandu sangat berpengaruh pada tinggi rendahnya kunjungan masyarakat ke posyandu.

\section{Hubungan Pengetahuan Ibu terhadap Partisipasi Ibu Membawa Balita ke Posyandu}

Berdasarkan hasil penelitian didapat bahwa bahwa responden pengetahuan tinggi dengan partisipasi aktif sebanyak 23 orang $(85,2 \%)$. Hasil uji statistik didapatkan nilai $p$-value adalah 0,015 $(\mathrm{p}<0,05)$. Sehingga dapat disimpulkan adanya hubungan antara pengetahuan ibu terhadap partisipasi ibu membawa balita ke posyandu.

Hasil penelitian ini sejalan dengan penelitian yang dilakukan diperoleh proporsi responden berpengetahuan baik dan berprilaku kunjungan baik sebesar $82,3 \%$ dengan nilai $p$-value $0,006 .{ }^{20}$

Menurut hasil penelitian dapat dinyatakan bahwa ada pengaruh pengetahuan dengan partisipasi masyrakat dalam berkunjung keposyandu dengan hasil uji statistik $\mathrm{p}=0,000<\alpha=0,05$. Beberapa faktor yang mempengaruhi kunjungan ibu ke posyandu secara rutin untuk memeriksakan balitanya antara lain kemauan dan niat ibu untuk mendapatkan informasi dan pelayanan kesehatan untuk anaknya. Informasi yang didapatkan dari posyandu diharapkan akan mencegah masalah tumbuh kembang pada anak karena kesadaran ibu tentang tumbuh kembang anak yang tinggi. ${ }^{21}$

Pengetahuan sangat diperlukan dalam tumbuh kembang anak. Sehingga pengetahuan orang tua tentang tumbuh kembang anak sangat menentukan keberhasilan orang tua dalam membesarkan anaknya. Tingkat pendidikan orang tua yang tinggi diharapkan akan memiliki tingkat pengetahuan yang lebih tinggi juga, hal ini dikarenakan semakin tinggi tingkat pendidikan seseorang maka semakin mudah baginya untuk mendapatkan dan mencari informasi.

\section{Kesimpulan}

Hasil Penelitian menunjukan bahwa mayoritas responden pendidikan tinggi, myoritas responden bekerja, mayoritas responden berjarak dekat dengan posyandu, mayoritas responden pengetahuan baik, dan mayoritas responden berpartisipasi aktif di posyandu. Dari hasil uji statistik menunjukkan bahwa ada hubungan antara pendidikan ibu terhadap partisipasi ibu membawa balita ke posyandu dengan hasil analisa $p$-value 0,026 ( $p$-value $<0,05)$. Dari hasil uji statistik menunjukkan bahwa ada hubungan antara pekerjaan ibu terhadap partisipasi ibu membawa balita ke posyandu dengan hasil analisa $p$-value 0,001 (p-value $<0,05$ ). Dari hasil uji statistik menunjukkan bahwa ada hubungan jarak ke posyandu terhadap partisipasi ibu membawa balita ke posyandu dengan hasil analisa $p$-value 0,000 (p-value $<0,05$ ). Dari hasil uji statistik menunjukkan bahwa ada hubungan antara pengetahuan ibu terhadap partisipasi ibu membawa balita ke posyandu dengan hasil analisa $p$ value 0,015 ( $\mathrm{p}$-value $<0,05$ ).

Diharapkan dengan adanya hasil penelitian ini partisipasi masyarakat terutama ibu-ibu pada kegiatan posyandu rutin dilaksanakan dapat dijaga dan ditingkatkan. Perlunya partisipasi dari sektor seperti anggota masyarakat lainnya, pemerintah maupun swasta. Pengembangan kemadirian masyarakat harus berkelanjutan. Perlunya perhatian pemerintah dalam menyediakan sarana dan prasarana yang diperlukan dalam penyelenggaraan kegiatan posyandu. Sektor swasta diharapkan dapat memenuhi tanggung jawab sosialnya dalam mendukung kegiatan posyandu.

\section{Konflik Kepentingan}




\section{J INDONESIA JOURNAL of Miduifery SCIENCES}

Penelitian ini tidak ada konflik kepentingan apapun baik secara individu maupun organisasi

\section{Ucapan Terima Kasih}

Terimakasih kepada semua responden yang telah berkontribusi pada penelitian ini

\section{Pendanaan}

Sumber pendanaan pada penelitian ini adalah individu.

\section{References}

1. Atika. Pemasyarakatan Buku Kesehatan Ibu dan Anak di Indonesia. Depok; 2010.

2. Arikunto.. Metodelogi Penelitian. Jakarta : Rhineka Cipta; 2006

3. Azwar, S. Sikap Manusia, Teori Dan Pengukurannnya Edisi ke 2. Yogyakarta: Pustaka Pelajar; 2011.

4. Departemen Kesehatan Republik Indonesia. Profil Kesehatan Indonesia 2009. Jakarta; 2010.

5. Dinkes Provinsi Jawa Barat. Profil Dinas Kesehatan Provinsi Jawa Barat. Jawa Barat; 2012.

6. Hardjono. Faktor-faktor yang mempengaruhi partisipasi masyarakat untuk hidup sehat. Depok : UI; 2010.

7. Hastono. Analisis data kesehatan. Depok : FKM UI; 2007.

8. Halomoan, Tagor. Hubungan Partisipasi Ibu Balita Di Posyandu Dengan Pengetahuan, Sikap, Dan Perilaku Gizi Ibu Balita Serta Status Gizi Balita Di Kecamatan Tamansari, Kabupaten Bogor. Bogor; 2012.

9. Hidayat AA. Pengantar Imu Keperawatan Anak I. Jakarta: Direktorat Jenderal Pendidikan Tinggi; 2008.

10. Hockenberry, M.J \& Wilson, D. Essential of Pediatric Nursing. St. Louis Missoury: Mosby; 2016.

11. Koto, NO. Faktor-faktor yang berhubungan dengan perilaku kunjungan ibu yang mempunyai balita ke posyandu di Wilayah kerja Puskesmas Kota Solok tahun 2011. Depok : UI; 2011.

12. Muaris. Hubungan antara Pemberian Makanan Tambahan Dengan Tingkat Kunjungan Ke Pelayanan Kesehatan di Kelurahan Sine Sragen. Yogyakarta; 2006.

13. Muhaemin, A Beberapa Faktor Yang Berhubungan Dengan Partisipasi Ibu Balita Dalam Kegiatan Penimbangan Di Posyandu (Studi Kasus Di Desa Sidorejo Bendosari Sukoharjo); 2008.

14. Notoatmodjo, S. Promosi Kesehatan Teori dan Aplikasi. Jakarta: Rineka Cipta; 2012.

15. Nursalam. Konsep dan Penerapan Metedologi Penelitian Ilmu Keperawatan. Jakarta : Salemba Medika; 2011.

16. Octaviani. Analisis Faktor Yang Berhubungan Dengan Partisipasi Kader Dalam Kegiatan Posyandu di Wilayah Puskesmas Jogonalon II Kabupaten Klaten; 2008.

17. Puspitasari, Ita. Faktor - Faktor Yang Mempengaruhi Partisipasi Ibu Balita Ke Posyandu Kencursari I Di Dukuh Tegaltandan Desa Banguntapan Kabupaten Bantul. Yogyakarta; 2015.

18. Reihana, Duarsa. Faktor-faktor Yang Berhubungan Dengan Partisipasi Ibu Untuk Menimbang Balita ke Posyandu. Jakarta; 2012.

19. Suryaningsih, H. Faktor-Faktor yang Berhubungan dengan Perilaku Kunjungan Ibu Bayi dan Balita ke Posyandu Di Puskesmas Kemiri Muka Kota Depok Tahun 2012. Depok : UI; 2012.

20. Sutomo. B. dan Anggraeni. DY. Faktor-faktor yang berhubungan dengan kunjungan ibu-ibu belita ke posyandu di kelurahan Bojongherang Kabupaten Cianjur tahun 2010. Depok : UI; 2010.

21. Unicef. The State Of the World's Children; 2012.

22. WHO. The World Health Report 2012. http://www.who.int./whr/2012/en/index.html. Diakses 09 April 2018; 2012.

23. Wong, Donna L., dkk. Buku Ajar Keperawatan Pediatrik Volume 1, Jakarta; 2012.

24. Zulkifli. Posyandu dan Kader Kesehatan. USU Digital Library. http://www.library.usu.ac.id . Diakses pada 09 April 2018; 2003.

25. Kurnia, Nita. Faktor-Faktor Yang Berhubungan Dengan Partisipasi Ibu Balita Dalam Pemanfaatan Pelayanan Gizi Balita Di Posyandu Kelurahan Sukasari Kecamatan Tangerang Kota Tangerang. Skripsi. 


\section{J INDONESIA JOURNAL \\ Ms of Miduifery SCIENCES}

Program Studi KesehatanMasyarakat Fakultas Kedokteran dan Ilmu Kesehatan Universitas Islam Negeri Syarif Hidayatullah Jakarta; 2011. 